\title{
STUDI PENGARUH TEBAL TANAH LUNAK DAN GEOMETRI TIMBUNAN TERHADAP STABILITAS TIMBUNAN
}

\author{
Andryan Suhendra ${ }^{1}$ \\ ${ }^{1}$ Civil Engineering Department, Faculty of Engineering, Binus University \\ Jl. KH Syahdan No. 9, Palmerah, Jakarta Barat, 11480 \\ 1asuhendra@binus.edu
}

\begin{abstract}
The stability of embankment over soft soil is influenced by several factors such as subsoil and filling material properties, embankment geometry, ground water level and working load. This paper will present the analysis of influencing of soft soil thickness and embankment geometry to the stability of embankment. The analysis will be conducted using Slope/W by varying the thickness of soft soil and embankment geometry with certain embankment height and soft soil and fill material properties. The thickness of soft soil is varies in range of $2 \mathrm{~m}$ to $15 \mathrm{~m}$, whereas the slope of embankment is varies in 4 condition i.e. 1:1 (vertical : horizontal), 1:1.5, 1:2, and 1:2.5, as well as the top width of embankment from $10 \mathrm{~m}$ to $40 \mathrm{~m}$, with the output is factor of safety of embankment. The analysis result show the factor of safety is decreased when the top side of embankment is wider as well as when the slope of embankment is gentler. The analysis also show the influence of soft soil thickness to the embankment stability is limited to certain depth only that is in range of $7 \mathrm{~m}$ to $10 \mathrm{~m}$, then the factor of safety remains constant.
\end{abstract}

Keywords: embankment stability, soft soil, Slope/W, factor of safety

\begin{abstract}
ABSTRAK
Stabilitas konstruksi timbunan di atas tanah lunak dipengaruhi oleh berbagai faktor seperti parameter tanah timbunan dan tanah dasar, geometri timbunan, muka air tanah dan beban kerja. Paper ini akan menyajikan analisa mengenai besar pengaruh ketebalan tanah lunak dan geometri timbunan terhadap stabilitas konstruksi timbunan. Analisa akan dilakukan dengan menggunakan program Slope/W dengan membuat variasi ketebalan tanah lunak dan geometri timbunan yaitu kemiringan lereng timbunan dan lebar sisi atas timbunan untuk parameter tanah timbunan dan tanah dasar serta tinggi timbunan tertentu. Variasi ketebalan tanah lunak dimulai dari $2 \mathrm{~m}$ hingga mencapai $15 \mathrm{~m}$, sedangkan kemiringan lereng timbunan divariasikan sebanyak 4 jenis yaitu 1:1 (vertical:horizontal, 1:1,5, 1:2 hingga 1:2,5, demikian pula untuk lebar sisi atas timbunan dibuat 4 variasi mulai dari $10 \mathrm{~m}$ hingga $40 \mathrm{~m}$. Dari hasil analisa menunjukkan bahwa semakin lebar timbunan yang dibuat maka faktor keamanan akan semakin menurun, demikian juga jika kemiringan lereng timbunan dilandaikan. Hasil analisa juga menunjukkan pengaruh ketebalan tanah lunak pada stabilitas konstruksi timbunan terbatas hingga kedalaman tertentu, yaitu pada $7 \mathrm{~m}$ hingga $10 \mathrm{~m}$ maka faktor keamanan cenderung sudah konstan.
\end{abstract}

Kata kunci: stabilitas timbunan, tanah lunak, slope/w, faktor keamanan 


\section{PENDAHULUAN}

Dalam menganalisa stabilitas timbunan di atas tanah lunak diperlukan data-data yang lengkap dan detail, namun seringkali data-data yang tersedia tidak memenuhi persyaratan dan terkadang melampaui yang diperlukan. Dari segi keperluan analisa dan biaya, jumlah data yang berlebih atau melampaui dari yang diperlukan kadang-kadang menjadi kurang bermanfaat dan boros. Misalnya dalam penentuan kedalaman penyelidikan tanah yang untuk mudahnya seringkali dilakukan penyelidikan tanah yang terlalu dalam sehingga menghabiskan biaya yang tidak sedikit. Oleh karena itu dalam makalah ini akan dibahas mengenai prilaku kelongsoran yang mungkin terjadi pada timbunan di atas tanah lunak termasuk kedalaman kelongsoran yang mungkin terjadi untuk berbagai kondisi.

Tujuan dari penelitian ini adalah untuk mendapatkan hubungan antara tebal lapisan tanah lunak dan geometri timbunan terhadap stabilitas konstruksi timbunan. Dari hasil analisa diharapkan dapat diambil manfaat berupa panduan awal dalam analisa stabilitas konstruksi timbunan di atas tanah lunak. Chakravarthi dan Ramu (2011) mengemukakan bahwa ketebalan tanah lunak sangat berpengaruh terhadap stabilitas kontruksi timbunan yang dibangun di atasnya.

\section{METODE}

Penelitian yang dilakukan dengan cara melakukan analisa secara teoritis terhadap berbagai data analisa yang terdiri dari tanah dasar dan parameternya, timbunan dan kondisi konstruksi timbunannya, dan metode analisa.

\section{Tanah Dasar}

Tanah dasar merupakan tanah lempung lunak jenuh air dengan batasan data (Parameter) adalah satu lapis yang homogen dengan properti dengan berat volume $(\gamma) 16 \mathrm{kN} / \mathrm{m}^{3}$, kohesi (c) 10 $\mathrm{kN} / \mathrm{m}^{2}$, dan sudut geser dalam $(\phi) 0^{\circ}$, ketebalan tanah dasar divariasikan mulai dari $2 \mathrm{~m}$ hingga $15 \mathrm{~m}$, Muka air tanah diasumsikan terletak di permukaan tanah dasar dan Lebar tanah dasar yang digunakan dibatasi $80 \mathrm{~m}$ diukur dari tengah timbunan

\section{Timbunan}

Ada 2 kondisi konstruksi timbunan yang dijadikan dasar dalam penelitian. Untuk mengetahui pengaruh lebar dan kemiringan lereng timbunan terhadap stabilitas timbunan, digunakan tinggi timbunan $3 \mathrm{~m}$ dengan kemiringan dan lebar sisi atas yang bervariasi yaitu variasi kemiringan 1 : 1; $1: 1,5 ; 1: 2$; dan $1: 2,5$ dan variasi lebar sisi atas $10 \mathrm{~m}, 20 \mathrm{~m}, 30 \mathrm{~m}$, dan $40 \mathrm{~m}$. Untuk mengetahui pengaruh kedalaman dan tinggi timbunan, maka digunakan tinggi timbunan yang bervariasi dengan lebar sisi atas timbunan sebesar $20 \mathrm{~m}$ dan kemiringan lereng timbunan diambil bervariasi $1: 1$ hingga $1: 2,5$.

\section{Metode Analisa}

Analisa stabilitas dilakukan dengan menggunakan bantuan program Slope/W yang dibatasi dengan pola kelongsoran berbentuk lingkaran. 


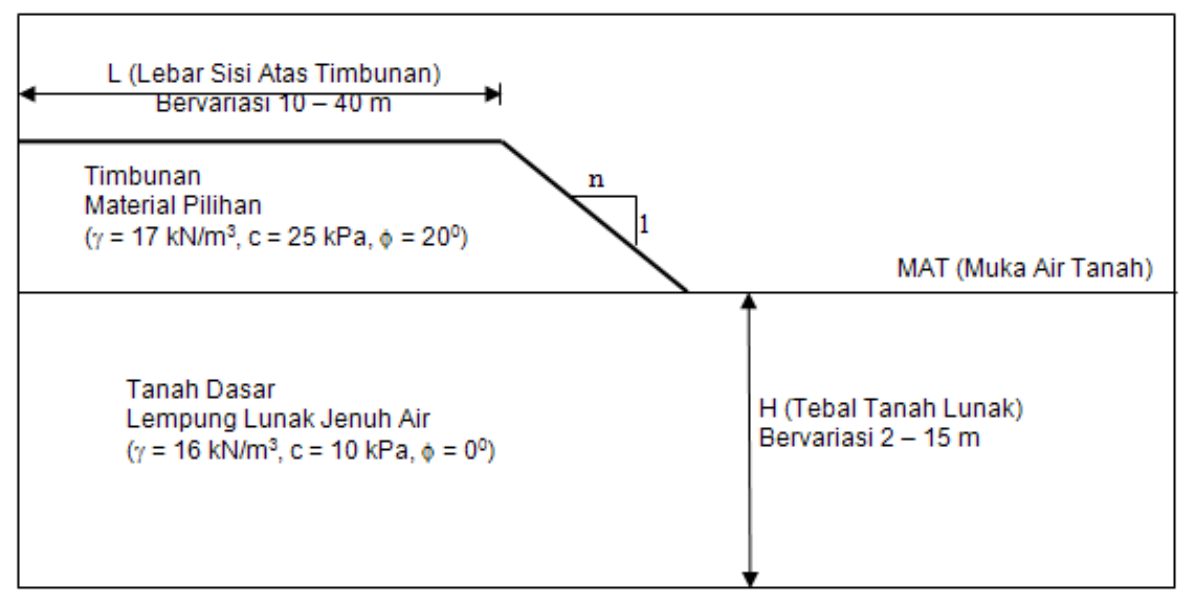

Gambar 1 Potongan Melintang Tipikal Konstruksi Timbunan

\section{Tinjauan Pustaka}

Stabilitas timbunan di atas tanah lunak sangat dipengaruhi oleh berbagai faktor yaitu tingkat kekerasan tanah dasar, tinggi timbunan dan beban kerja di atasnya. Selain faktor-faktor di atas, diyakini bahwa ketebalan tanah lunak, lebar timbunan dan kemiringan timbunan juga berpengaruh terhadap tingkat stabilitas timbunan seperti yang akan dilakukan analisa dalam penelitian ini.

Salah satu prinsip dasar dalam analisa stabilitas konstruksi timbunan di atas tanah lunak adalah membandingkan antara gaya pendorong (penyebab) kelongsoran dan gaya penahan. Gaya pendorong umumnya disebabkan oleh berat sendiri konstruksi timbunan dan beban kerja, sedangkan gaya penahan merupakan kontribusi dari kuat geser tanah (Gambar 2). Berdasarkan konsep tersebut kemudian para ahli geoteknik mengemukakan berbagai teori (rumus) yang bisa digunakan dalam melakukan analisa stabilitas ini misalnya Janbu, Bishop, Morgenstern-Price dan lain sebagainya.

Ada 2 pendekatan yang diusulkan oleh para ahli geoteknik tersebut dalam melakukan analisa stabilitas tersebut yaitu: (1) Pendekatan melalui perbandingan gaya-gaya yang bekerja (metode gaya). (2) Pendekatan melalui perbandingan momen yang bekerja (Metode Momen)

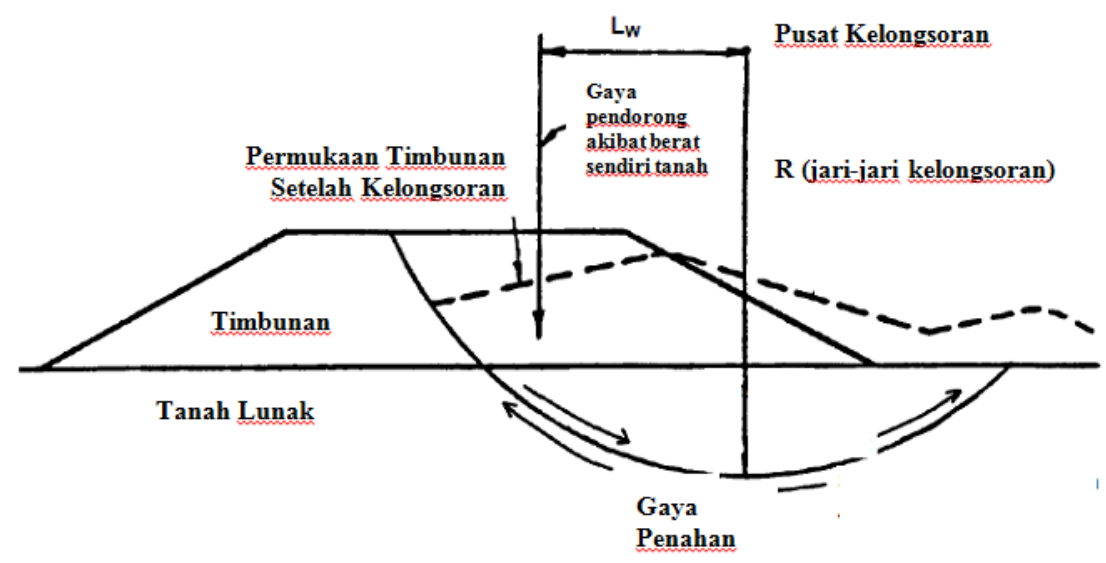

Gambar 2 Ilustrasi pola kelongsoran 
Berikut ini adalah contoh formula yang diusulkan oleh para ahli geoteknik terkait dengan analisa stabilitas kelongsoran (Burman et. al., 2015; Das et. al., 2013; Huang, 2014) yang terdiri dari Metode Gaya menurut Bishop dan Metode Momen.

\section{Metode Gaya Menurut Bishop}

Prinsip dari metode Bishop ini adalah dengan membagi bidang kelongsoran menjadi bagianbagian yang lebih kecil (Gambar 3).

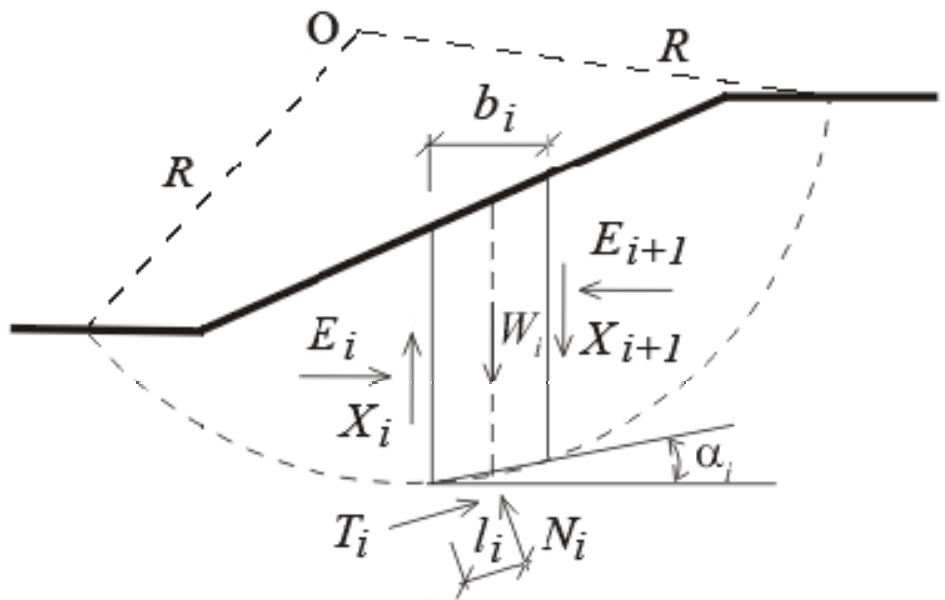

Gambar 3 Metode Irisan dari Bishop

Setiap bagian kecil tersebut kemudian dihitung beratnya masing-masing (Yang merupakan gaya pendorong). Sedangkan Gaya penahan diperoleh dari kuat geser tanah dasar dan timbunan (c dan $\phi)$. Kemudian faktor keamanan diperoleh dari perbandingan antara gaya penahan dan pendorong seperti terlihat pada rumus berikut ini.

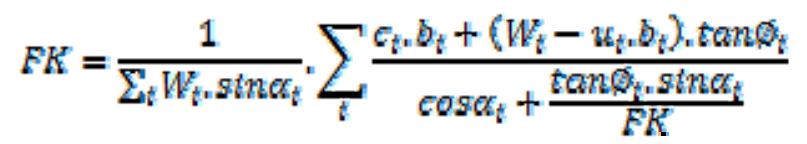

$\mathrm{FK}=$ faktor keamanan

$\mathrm{C}_{\mathrm{i}}=$ kohesi efektif tanah pada irisan $\mathrm{i}$

$\mathrm{b}_{\mathrm{i}}=$ lebar irisan $\mathrm{i}$

$\mathrm{W}_{\mathrm{i}}=$ berat tanah irisan $\mathrm{i}$

$\mathrm{u}_{\mathrm{i}} \quad=$ tegangan air pori

$\phi_{\mathrm{i}}=$ sudut geser dalam efektif

$\alpha_{\mathrm{i}}=$ sudut kemiringan bidang longsor irisan $\mathrm{i}$

\section{Metode Momen}

Pada metode ini yang diperbandingkan adalah momen penahan dan momen pendorong (Gambar 2). Kuat geser tanah memberikan kontribusi pada momen penahan, sedangkan momen pendorong terjadi akibat dari berat tanah timbunan dan beban luar seperti ditunjukkan dalam formula berikut ini. 


$$
F K=\frac{\text { Momen Penahan }}{\text { Momen Pendorong }}=\frac{c_{\cdot} L_{\cdot} R}{W^{\prime} \cdot W^{2}}
$$

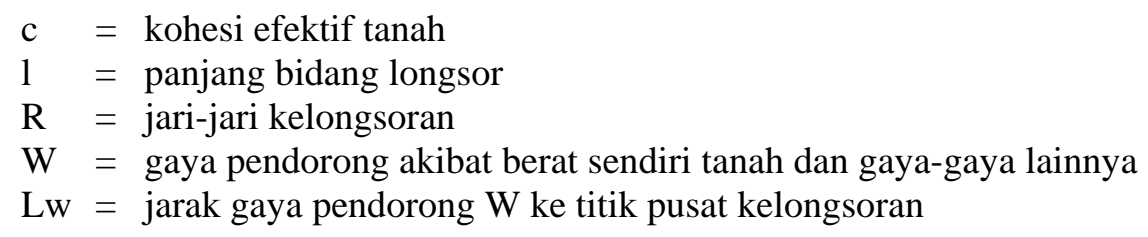

Dalam studi ini akan dilakukan analisa stabilitas kontruksi timbunan dengan menggunakan bantuan sub-program komputer Geo-Studio yaitu Slope/W (Krahn, 2014) yang berdasarkan metode kesetimbangan batas (limit equilibrium method). Hasil dari program Slope/W ini berupa faktor keamanan dan bidang kelongsoran yang mungkin terjadi. Nilai faktor keamanan yang disajikan dalam tulisan ini mengacu pada metode Bishop.

\section{HASIL DAN PEMBAHASAN}

Bentuk kelongsoran yang dijadikan dasar analisa dalam tulisan ini adalah yang berbentuk lingkaran dengan kelongsoran pada badan timbunan diabaikan. Berikut ini beberapa contoh dari hasil analisa menggunakan program Slope/W.

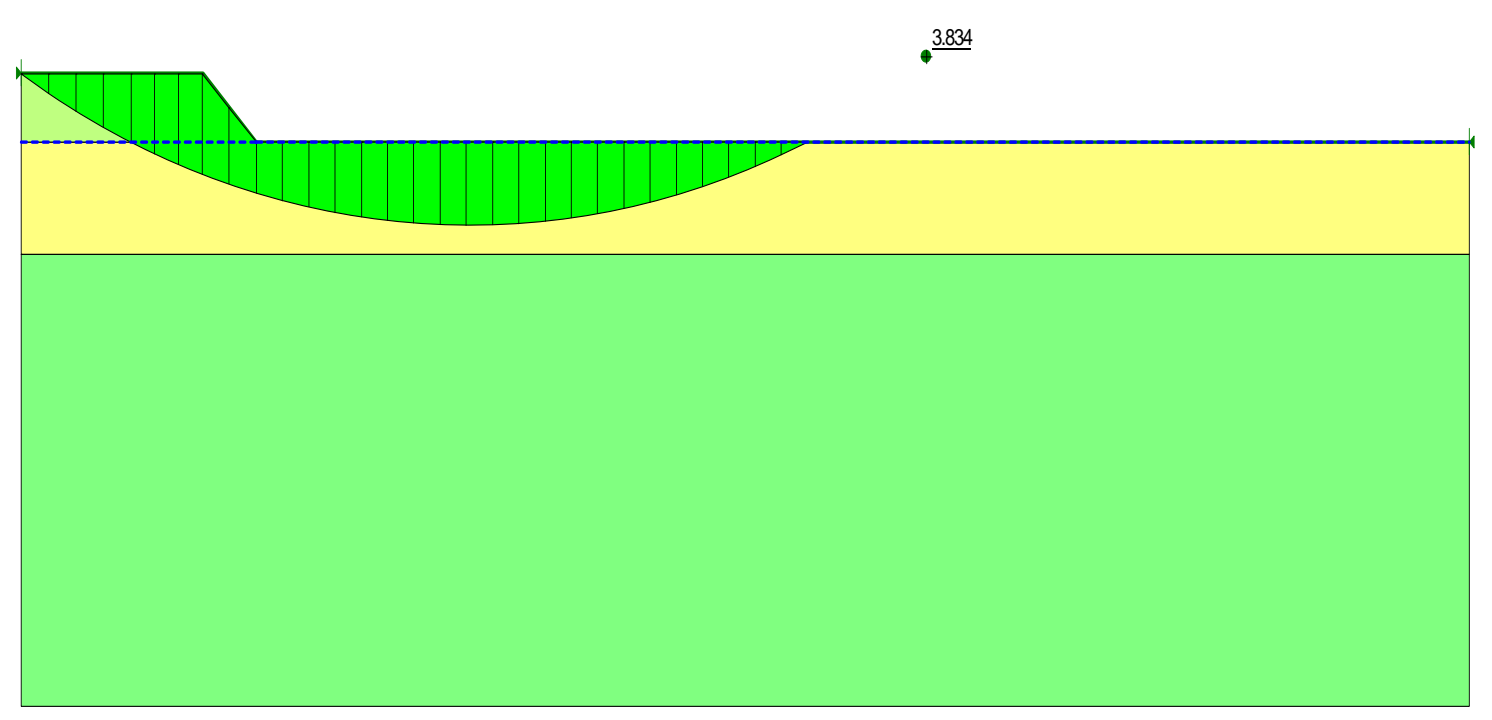

Gambar 4 Hasil Keluaran Slope/W untuk Lebar Timbunan 20 m, Kemiringan Lereng 1:1 dan Kedalaman Tanah Lunak 5 m $(\mathrm{FK}=3,834)$ 


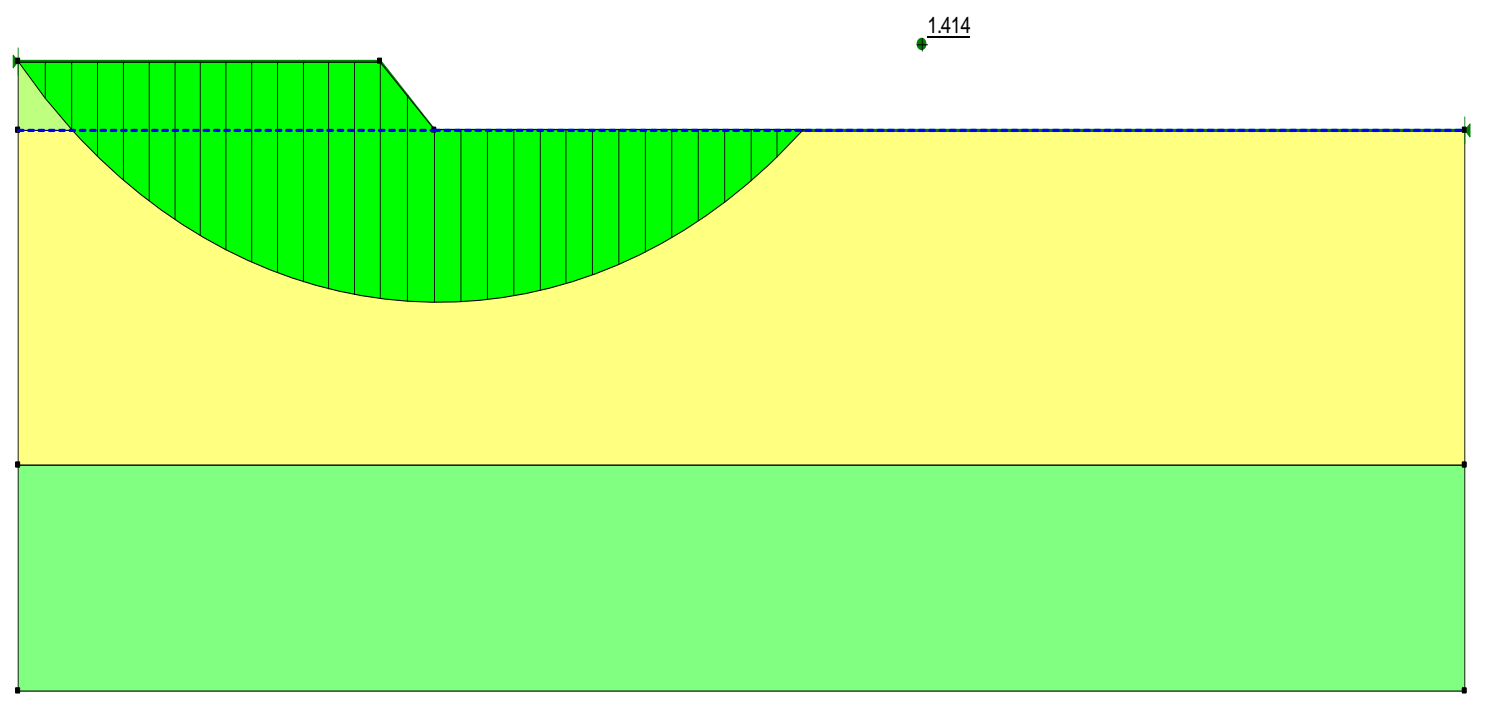

Gambar 5 Hasil Keluaran dari Program Slope/W untuk Lebar Timbunan 40 m, Kemiringan lereng 1:1 dan Kedalaman Tanah Lunak 15 m $(\mathrm{FK}=1,414)$

Ada tiga hasil perhitungan yang akan disajikan dan dianalisa dalam tulisan ini yaitu pengaruh lebar timbunan dan kedalaman lunak, pengaruh kemiringan lereng timbunan dan kedalaman tanah lunak, dan hubungan antara tinggi timbunan dan kedalaman kelongsoran yang mungkin terjadi.

\section{Pengaruh Lebar Timbunan dan Kedalaman Tanah Lunak}

Analisa dilakukan dengan membuat variasi lebar timbunan dan kedalaman tanah lunak, sedangkan tinggi timbunan digunakan satu jenis yaitu $3 \mathrm{~m}$. Hasil dari program Slope/W berupa faktor keamanan seperti disajikan dalam Tabel 1 dan Gambar 6.

Tabel 1 Faktor Keamanan untuk Berbagai Variasi Lebar Timbunan

\begin{tabular}{|c|c|c|c|c|c|c|c|c|c|c|c|c|c|c|c|c|}
\hline \multirow{3}{*}{$\begin{array}{c}\text { Kedalaman } \\
\text { Tanah Lunak } \\
\text { (m) }\end{array}$} & \multicolumn{4}{|c|}{ Kemiringan Lereng $1: 1$} & \multicolumn{4}{|c|}{ Kemiringan Lereng $1: 1,5$} & \multicolumn{4}{|c|}{ Kemiringan Lereng $1: 2$} & \multicolumn{4}{|c|}{ Kemiringan Lereng $1: 2,5$} \\
\hline & \multicolumn{4}{|c|}{ Lebar Timbunan (m) } & \multicolumn{4}{|c|}{ Lebar Timbunan (m) } & \multicolumn{4}{|c|}{ Lebar Timbunan (m) } & \multicolumn{4}{|c|}{ Lebar Timbunan (m) } \\
\hline & 10 & 20 & 30 & 40 & 10 & 20 & 30 & 40 & 10 & 20 & 30 & 40 & 10 & 20 & 30 & 40 \\
\hline 2 & *) & 452 & 5,635 & 4,672 & *) & 7,815 & 5,440 & 4,605 & 14,998 & 7,296 & 5,274 & 4,553 & 12,791 & 6,872 & 5,134 & 4,515 \\
\hline 3 & $\left.{ }^{*}\right)$ & 452 & 5,635 & 140 & *) & 15 & $5,33 /$ & $3,00 /$ & 14,998 & 7,296 & 756 & 2,894 & | 12.791 & 6,872 & 15 & 2,803 \\
\hline 4 & 7,915 & 3,834 & 2,820 & 2,469 & 6,758 & 3,619 & 2,748 & 2,450 & 5,934 & 3,439 & 2,688 & 2,438 & 5,321 & 3,289 & 2,638 & 2,350 \\
\hline 5 & 15 & 834 & 2,673 & D & 6,758 & 9 & & 82 & 34 & & & & 21 & 39 & 74 & 1,823 \\
\hline 6 & 4,711 & 2,546 & 1,944 & 1,741 & 4,145 & 2,421 & 1,902 & 1,704 & 3,721 & 2,316 & 1,866 & 1,648 & 3,395 & 2,227 & 1,839 & 1,604 \\
\hline 7 & 11 & 546 & 1, & 553 & 4,145 & $\frac{1}{1}$ & 1, & +1 & 3,721 & 6 & 66 & $I$ & 5 & 27 & 20 & 1,480 \\
\hline 8 & 3,491 & 2,000 & 1,557 & 1,414 & 3,117 & 1,909 & 1,527 & 1,410 & 2,830 & 1,833 & 1,502 & 1,411 & 2,604 & 1,768 & 1,483 & 1,416 \\
\hline 9 & 3,491 & 2,000 & 1,557 & 1,414 & 3,117 & 1,909 & 1,527 & 1,409 & 2,830 & 1,833 & 1,502 & 1,402 & 2,604 & 1,768 & 483 & 1,399 \\
\hline 10 & 3,491 & 2,000 & 1,557 & 1,414 & 3,117 & 1,909 & 1,527 & 1,409 & 2,830 & 1,833 & 502 & 1,402 & 604 & 1,768 & 483 & 1,399 \\
\hline 11 & 3,491 & 2,000 & 1,557 & 1,414 & 3,117 & 1,909 & 1,527 & 1,409 & 2,830 & 1,833 & 1,502 & 1,402 & 2,604 & 1,768 & 1,483 & 1,399 \\
\hline 12 & 3,491 & 2,000 & 1,557 & 1,414 & 3,117 & 1,909 & 1,527 & 1,409 & 2,830 & 1,833 & 1,502 & 1,402 & 604 & 1,768 & 483 & 1,399 \\
\hline 13 & 3,491 & 2,000 & 1,557 & 1,414 & 3,117 & 1,909 & 1,527 & 1,409 & 2,830 & 1,833 & 1,502 & 1,402 & 2,604 & 1,768 & 1,483 & 1,399 \\
\hline 14 & 3,491 & 2,000 & 1,557 & 1,414 & 3,117 & 1,909 & 1,527 & 1,409 & 2,830 & 1,833 & 1,502 & 1,402 & 2,604 & 1,768 & 1,483 & 1,399 \\
\hline 10 & 3,491 & 2,000 & 1,557 & 1,414 & 3,117 & 1,909 & 1,527 & 1,409 & 2,830 & 1,833 & 1,502 & 1,402 & 2,604 & 1,768 & 1,483 & 1,399 \\
\hline
\end{tabular}

Catatan : *) kelongsoran terjadi pada badan timbunan sehingga tidak dimasukkan dalam analisa 
Mengacu pada tabel 1 dan gambar 6 tersebut, terlihat bahwa semakin lebar sisi atas timbunan maka faktor keamanan konstruksi timbunan akan semakin menurun. Hal ini berlaku untuk semua kemiringan lereng yang dianalisa.

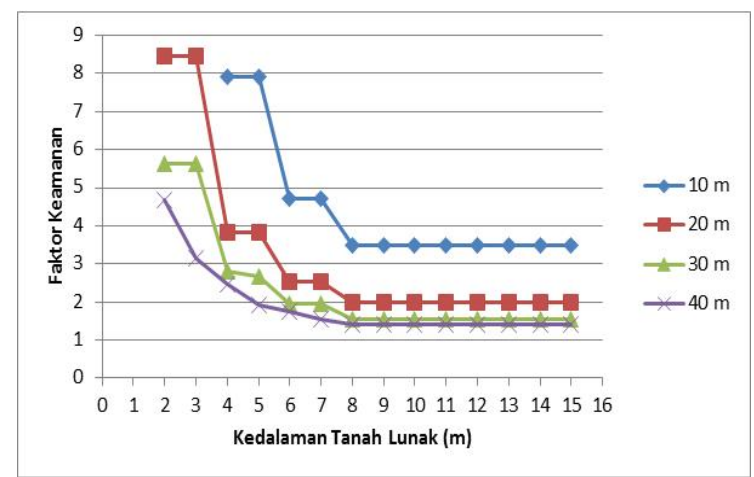

a. Kemiringan lereng $1: 1$

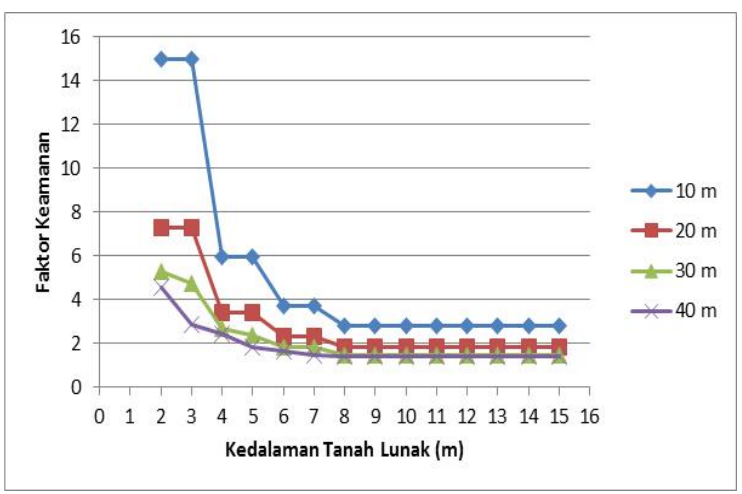

c. Kemiringan lereng $1: 2$

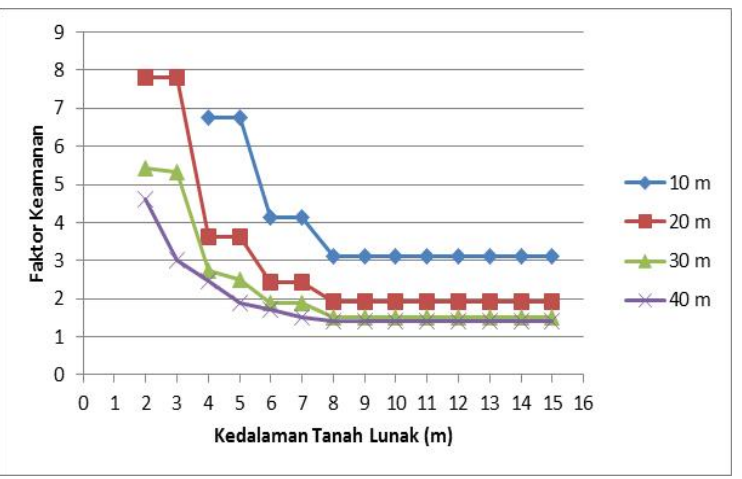

b. Kemiringan lereng $1: 1,5$

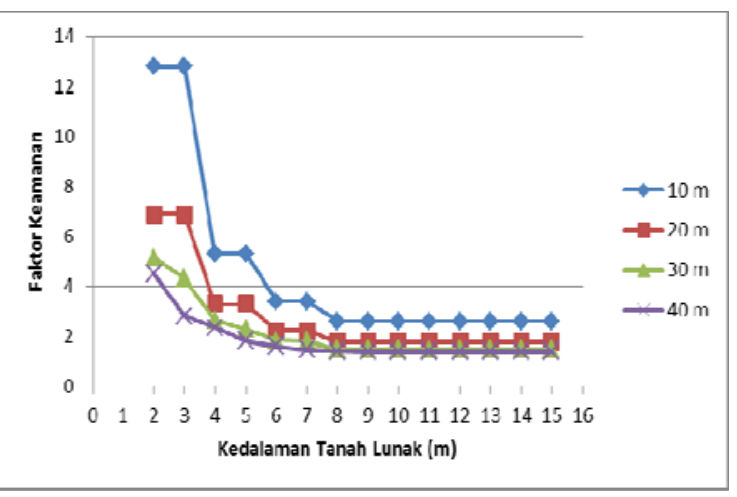

d. Kemiringan lereng $1: 2,5$

Gambar 6 Hubungan Antara Lebar Timbunan dan Faktor Keamanan

\section{Pengaruh Kemiringan Lereng Timbunan dan Kedalaman Tanah Lunak}

Analisa ini dilakukan untuk melihat pengaruh dari kemiringan lereng timbunan dan kedalaman tanah lunak terhadap faktor keamanan timbunan seperti terlihat pada Tabel 2 dan Gambar 7 berikut ini. Data yang digunakan juga sama seperti pada analisa sebelumnya yaitu untuk ketinggian timbunan $3 \mathrm{~m}$, kemiringan lereng, lebar timbunan dan kedalaman tanah lunak dibuat bervariasi. Hasil yang disajikan dalam tabel 2 dan gambar 7 memperlihatkan bahwa semakin landai kemiringan lereng timbunan yang dibuat, maka semakin rendah stabilitas timbunan yang ditunjukkan dengan semakin turunnya nilai faktor keamanan dan berlaku untuk semua lebar timbunan yang dianalisa. 
Tabel 2 Faktor Keamanan untuk Berbagai Variasi Kemiringan Lereng

\begin{tabular}{|c|c|c|c|c|c|c|c|c|c|c|c|c|c|c|c|c|}
\hline \multirow{3}{*}{$\begin{array}{c}\text { Kedalaman } \\
\text { Tanah Lunak } \\
\text { (m) }\end{array}$} & \multicolumn{4}{|c|}{ Lebar Timbunan $10 \mathrm{~m}$} & \multicolumn{4}{|c|}{ Lebar Timbunan $20 \mathrm{~m}$} & \multicolumn{4}{|c|}{ Lebar Timbunan $30 \mathrm{~m}$} & \multicolumn{4}{|c|}{ Lebar Timbunan $40 \mathrm{~m}$} \\
\hline & \multicolumn{4}{|c|}{ Kemiringan Lereng } & \multicolumn{4}{|c|}{ Kemiringan Lereng } & \multicolumn{4}{|c|}{ Kemiringan Lereng } & \multicolumn{4}{|c|}{ Kemiringan Lereng } \\
\hline & $1: 1$ & $1: 1,5$ & $1: 2$ & $1: 2,5$ & $1: 1$ & $1: 1,5$ & $1: 2$ & $1: 2,5$ & $1: 1$ & $1: 1,5$ & $1: 2$ & $1: 2,5$ & $1: 1$ & $1: 1,5$ & $1: 2$ & $1: 2,5$ \\
\hline 2 & *) & $*)$ & 998 & 12,791 & 452 & 5 & 296 & 872 & 35 & 10 & 74 & 34 & 672 & 55 & 53 & J10 \\
\hline 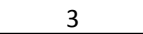 & $*)$ & c) & & 12.791 & 52 & & & 6,872 & & & & & & & & 803 \\
\hline 4 & 915 & 758 & 4 & 5,321 & 34 & 3 & 9 & 3, & 20 & & 88 & 38 & 69 & 50 & 38 & 350 \\
\hline 5 & 915 & 58 & 934 & 5,321 & 834 & 19 & 3,439 & 3,289 & 2,673 & 514 & 2,382 & 2,274 & 1,925 & 882 & 1,848 & 1,823 \\
\hline 6 & 711 & 4,145 & 3,721 & 3,395 & 2,546 & 2,421 & 2,316 & 2,227 & 1,944 & 1,902 & 1,866 & 1,839 & 1,741 & 704 & 1,648 & 1,604 \\
\hline 1 & 711 & 4,145 & 3,721 & 3,395 & 2,546 & 2,421 & 2,316 & 2,227 & 1,944 & 1,902 & 1,866 & 1,820 & 1,553 & 521 & 1,497 & 1,480 \\
\hline 8 & 491 & 117 & 2,830 & 2,604 & 2,000 & 1,5 & 333 & 1,768 & 1,557 & 27 & 02 & 1,483 & 414 & 410 & 1,411 & 1,416 \\
\hline J & 91 & & 0 & 04 & 000 & & 33 & 768 & 57 & & 2 & 1,483 & 1,414 & 09 & 02 & 1,399 \\
\hline 10 & 91 & & & 04 & 2,000 & & 3 & 1,768 & & & 2 & 83 & & 09 & 22 & 1,399 \\
\hline 1. & 3,491 & 17 & 2,830 & 2,604 & 2,000 & 1,909 & 1,833 & 1,768 & 1,557 & 77 & 1,502 & 1,483 & 414 & 409 & 02 & 1,399 \\
\hline 12 & 3,491 & 3,117 & 2,830 & 2,604 & 2,000 & 1,909 & 1,833 & 1,768 & 1,557 & 1,527 & 1,502 & 1,483 & 1,414 & 409 & 1,402 & 1,399 \\
\hline 13 & 3,491 & 3,117 & 2,830 & 2,604 & 2,000 & 1,909 & 1,833 & 1,768 & 1,557 & 1,527 & 1,502 & 1,483 & 1,414 & 409 & 1,402 & 1,399 \\
\hline 14 & 3,491 & 3,117 & 2,830 & 2,604 & 2,000 & 1,909 & 1,833 & 1,768 & 1,557 & 1,527 & 1,502 & 1,483 & 1,414 & 1,409 & 1,402 & 1,399 \\
\hline 15 & 3,491 & 3,117 & 2,830 & 2,604 & 2,000 & 1,909 & 1,833 & 1,768 & 1,557 & 1,527 & 1,502 & 1,483 & 1,414 & 1,409 & 1,402 & 1,399 \\
\hline
\end{tabular}

Catatan : *) kelongsoran terjadi pada badan timbunan sehingga tidak dimasukkan dalam analisa

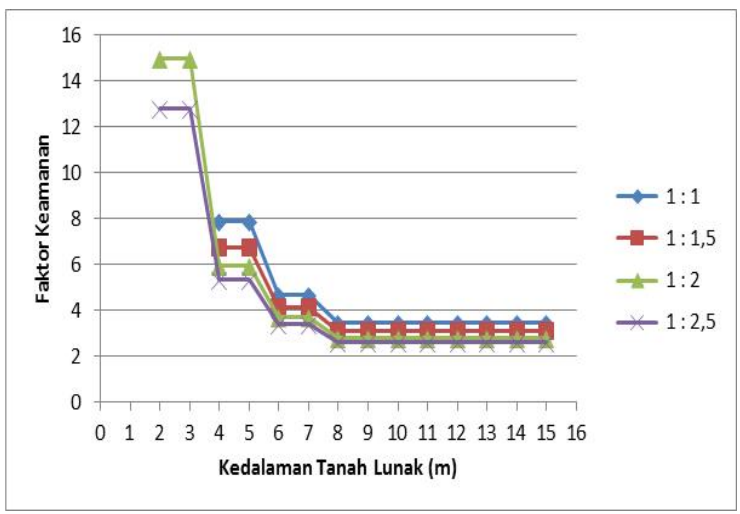

a. Lebar timbunan $10 \mathrm{~m}$

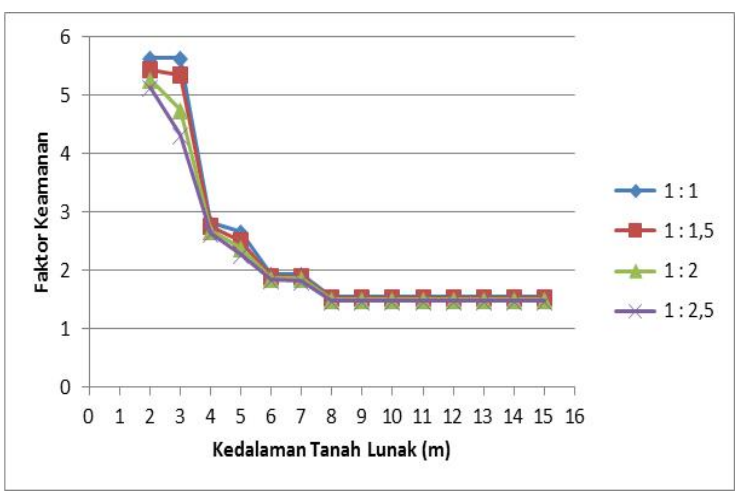

c. Lebar timbunan $=30 \mathrm{~m}$

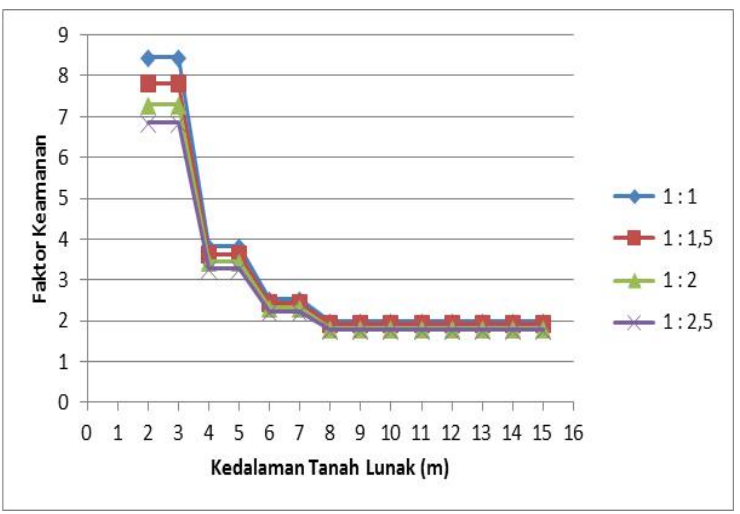

b. Lebar timbunan $20 \mathrm{~m}$

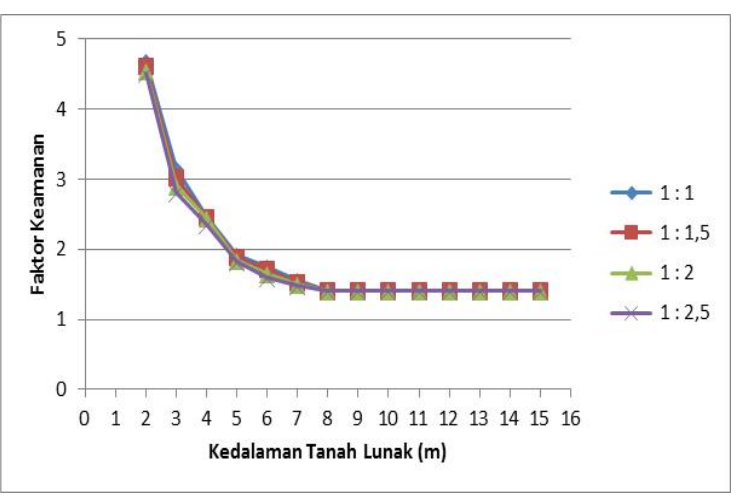

d. Lebar timbunan $=40 \mathrm{~m}$

Gambar 7 Hubungan antara faktor keamanan dan kemiringan lereng timbunan 


\section{Hubungan Antara Tinggi Timbunan dan Kedalaman Kelongsoran yang Mungkin Terjadi}

Hal lain yang akan dianalisa dalam tulisan ini adalah terkait dengan posisi garis kelongsoran yang paling kritis yang mungkin terjadi terkait dengan ketinggian timbunan yang akan dibangun. Melalui analisa ini diharapkan dapat diketahui hubungan antara ketinggian timbunan dan posisi garis kelongsoran. Analisa dilakukan dengan mengambil lebar timbunan $20 \mathrm{~m}$.

Tabel 3 Kedalaman Titik Gelincir untuk Berbagai Tinggi Timbunan

\begin{tabular}{|c|c|c|c|c|}
\hline \multirow{2}{*}{$\begin{array}{c}\text { Tinggi Timbunan } \\
(\mathrm{m})\end{array}$} & \multicolumn{4}{|c|}{ Kedalaman Titik Gelincir $(\mathrm{m})$} \\
\cline { 2 - 5 } & $1: 1$ & $1: 1,5$ & $1: 2$ & $1: 2,5$ \\
\cline { 2 - 5 } & 9,14 & 9,15 & 9,16 & 9,16 \\
\hline 1 & 8,40 & 8,43 & 8,44 & 8,45 \\
\hline 2 & 7,70 & 7,73 & 7,75 & 7,76 \\
\hline 3 & 7,00 & 7,05 & 7,08 & 7,09 \\
\hline 4 & 8,23 & 8,30 & 8,33 & 8,36 \\
\hline 5 & 7,52 & 7,60 & 7,65 & 7,68 \\
\hline 6 & 6,84 & 6,94 & 6,99 & 8,09 \\
\hline 7 & 7,90 & 8,02 & 8,10 & 8,15 \\
\hline 8 & 7,21 & 7,35 & 8,69 & 8,73 \\
\hline 9 & 6,54 & 7,94 & 9,27 & 10,58 \\
\hline 10 & &
\end{tabular}

Catatan : kedalaman titik gelincir diukur dari permukaan tanah dasar

Berdasarkan tabel 3 tersebut di atas, dapat diresumekan bahwa kedalaman garis kelongsoran yang paling kritis berada dalam rentang yang relatif kecil yaitu pada kedalaman 7 hingga $10 \mathrm{~m}$. Rentang kedalaman garis gelincir yang relatif kecil ini diperkirakan dipengaruhi oleh lebar tanah dasar, yaitu semakin lebar tanah dasar yang tersedia di lapangan maka akan semakin dalam garis kelongsoran kritis yang mungkin terjadi.

\section{SIMPULAN}

Selain dipengaruhi oleh parameter tanah dasar dan timbunan serta muka air tanah, stabitas timbunan juga dipengaruhi oleh ketebalan tanah lunak, kemiringan lereng timbunan dan lebar sisi atas timbunan. Semakin lebar timbunan yang akan dibangun maka akan semakin menurun stabilitas timbunan. Semakin landai kemiringan timbunan maka stabilitas timbunan juga semakin menurun. Kedalaman garis gelincir yang paling kritis untuk ketinggian timbunan 1-10 m dan lebar timbunan $20 \mathrm{~m}$ berada dalam rentang yang relatif kecil yaitu antara $7 \mathrm{~m}$ hingga $10 \mathrm{~m}$.

Perlu dilakukan simulasi yang lebih luas mencakup berbagai variasi ketinggian timbunan lain, ketebalan tanah lunak, kemiringan lereng timbunan dan termasuk lebar tanah dasar. Tulisan ini adalah hanya panduan awal, untuk ketepatan hasil perhitungan sesuai dengan kondisi lapangan maka perlu dilakukan analisa yang lebih detail. 


\section{DAFTAR PUSTAKA}

Burman, S. P., Acharya, R. R., Sahay, D. M. (2015). A Comparative Study of Slope Stability Analysis Using Traditional Limit Equilibrium Method and Finite Element Method. Asian Journal of Civil Engineering (Bhrc), 16(4): 467-492.

Chakravarthi, V. K., Ramu K. (2011). Stability Of Basal Reinforced Embankment On Soft SoilsEffect of Fill and Soft Soil Thickness on Reinforcement Force. Proceeding of Indian Geotechnical Conference (Paper K.159)

Das, B. M., Sobhan, K. (2013). Principles of Geotechnical Engineering (8th edition). Global Engineering

Huang, Y. H. (2014). Slope Stability Analysis by Limit Equilibrium Method. ASCE Press

Krahn, J. (2014). Stability Modelling with Slope/W (An Engineering Methodology). GEO-SLOPE/W International, Ltd. 